\title{
REVISTAMARACANAN
}

Dossiê

\section{Morgadios coloniais entre a nobilitação e o mercado: Trajetória e patrimônio de Francisco Barreto de Menezes, restaurador do Recife}

\author{
Colonial "morgadios" between the ennoblement and marketing \\ Trajectory and patrimony of Francisco Barreto de Menezes, restorative of \\ Recife
}

Ronaldo Vainfas*

Universidade Federal Fluminense

Niterói, Rio de Janeiro, Brasil

Márcia Motta**

Universidade Federal Fluminense Niterói, Rio de Janeiro, Brasil

Recebido em: 03 out. 2019.

Aprovado em: $12 \mathrm{dez} .2019$.

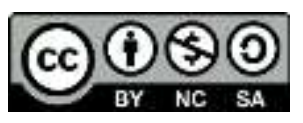

\footnotetext{
* Professor Titular aposentado do Instituto de História da Universidade Federal Fluminense. Professor Visitante do Programa de Pós-graduação em História Social da Universidade do Estado do Rio de Janeiro. Doutor em História Social pela Universidade de São Paulo; Mestre e Licenciado em História em História pela Universidade Federal Fluminense. (rvainfas@terra.com.br)

ORCID iD: https://orcid.org/0000-0003-0069-0374

CV Lattes: http://lattes.cnpq.br/2893624319383287

** Professora Titular do Instituto de História e do Programa de Pós-graduação em História da Universidade Federal Fluminense. Doutora em História pela Universidade Estadual de Campinas; Mestre e graduada em História pela Universidade Federal Fluminense. Coordenadora do INCT - "História Social das Propriedades e Direitos de Acesso" (CNPq, CAPES, FAPERJ). (menendesmotta9@gmail.com)

ORCID iD: https://orcid.org/0000-0002-5434-7515

CV Lattes: http://lattes.cnpq.br/9884509029282994
} 
Morgadios coloniais entre a nobilitação e o mercado: Trajetória e patrimônio de Francisco Barreto de Menezes, restaurador do Recife 


\title{
Resumo
}

O artigo versa sobre a trajetória de Francisco Barreto de Menezes, comandante da Insurreição Pernambucana contra os holandeses desde 1647, com foco na constituição de seu patrimônio e na instituição de um morgadio, em 1663. Discute-se a formação de morgadios no Brasil Colonial por iniciativa de funcionários da Coroa ligados à atividade mercantil, de preferência à herança fundiária típica da aristocracia portuguesa no Antigo Regime. A base documental do artigo reside no testamento do governador Francisco Barreto, comparado aos testamentos de outras lideranças luso-brasileiras da guerra pernambucana, a exemplo de João Fernandes Vieira, André Vidal de Negreiros e Antônio Telles da Silva.

Palavras-chave: Restauração Pernambucana. Francisco Barreto de Menezes. Engenhos Coloniais. Morgadios. Nobilitação.

\begin{abstract}
The article deals with the trajectory of Francisco Barreto de Menezes, commander in the restoration war of Pernambuco against the Dutch since 1647, focusing on the constitution of his patrimony and the establishment of a morgadio in 1663. It discusses the formation of morgadios in Colonial Brazil by the initiative of Crown officials linked to commercial activity, rather than the typical land inheritance of the Portuguese aristocracy in the Ancien Régime. The source of the article lies in the will of the Governor Francisco Barreto, compared to the wills of other LusoBrazilian leaders of the Pernambuco war, such as João Fernandes Vieira, André Vidal de Negreiros and Antonio Telles da Silva.
\end{abstract}

Keywords: Pernambuco Restoration. Francisco Barreto de Menezes. Colonial Sugarmills. Morgadios. Ennoblement. 


\section{Francisco Barreto e a capitulação do Recife}

Francisco Barreto de Menezes foi nada menos do que Mestre-de-Campo-General do Estado do Brasil, com patente expedida em 12 de fevereiro de 1647. Tal posto equivalia ao supremo comando da insurreição pernambucana irrompida em 1645 contra os holandeses, que somente haveriam de capitular em 1654. Em 28 de janeiro deste ano, segundo a narrativa de diversos cronistas das guerras pernambucanas, as tropas comandadas por Francisco Barreto fizeram sua entrada triunfal no Recife, ele e seus oficiais a cavalo, a soldadesca andrajosa, vários descalços e mal armados, diante de moradores atônitos, muitos apavorados.

Nos meses que antecederam a rendição do Recife, o Conselho Político que governava a cidade em nome da Companhia das Índias Ocidentais, a WIC (West Indische Compagnie) provocou enorme pânico na cidade. Para estimular uma última resistência, os governantes flamengos prenunciavam um massacre. Não faltavam, de fato, exemplos deste perigo iminente na medida em que o "exército restaurador" avançou desde 1645: execução sumária de holandeses e supostos aliados; confisco de propriedades, sequestro de escravos, saque de "dinheiro de contado", cavalos, gado de corte, mobiliário, jias e pratarias.

$\mathrm{Na}$ "guerra da liberdade divina"1 contra os "hereges calvinistas", os judeus portugueses foram ainda mais tripudiados pelo exército restaurador, antes de tudo porque o plano da insurreição vazou pela ação de judeus ou cristãos-novos residentes na várzea do Capibaribe, e, sobretudo, porque os judeus eram grandes credores da açucarocracia pernambucana, sobretudo porque que eram eles que vendiam, com juros, os escravos de Angola e da Guiné. ${ }^{2}$ A classe senhorial das "capitanias do norte" devia muito aos judeus portugueses.

Massacres à parte, a capitulação do Recife foi evento pacífico. O acordo para a rendição estava já acertado entre os membros do Conselho Político e Francisco Barreto nos mínimos detalhes. O general Francisco Barreto de Menezes cumpriu, com elegância, a proposta dos holandeses para depor as armas. Concedeu três meses para que os vencidos ajustassem seus negócios e deixassem o Brasil, levando seus bens. O prazo final foi fixado em 27 de abril, após o que o novo governo não mais garantiria nem os bens, nem as pessoas dos "antigos invasores". Os judeus portugueses foram inseridos no acordo, após muita negociação.

Na prática, os derrotados venderam tudo, por preço de ocasião, mas muita coisa foi deixada para trás. Como não havia, entre os portugueses católicos, quem pudesse ou quisesse comprar casas, terras ou engenhos à vista, holandeses e judeus abandonaram Pernambuco na condição de credores. O acordo da rendição era o único diploma legal comprobatório da derrota holandesa, mas não se firmou, em 1654, qualquer tratado luso-holandês sobre questões indenizatórias. Holandeses e judeus só foram reconhecidos como credores na década

\footnotetext{
${ }^{1}$ Assim João Fernandes qualificou a guerra contra os holandeses em 1645, mas uma de suas primeiras decisões foi abolir as dívidas que os aderentes à rebelião tivessem com os holandeses e judeus.

2 Após a conquista holandesa de Angola, a WIC decretou que a venda de escravos, em leilão público, só aceitaria pagamentos à vista. Eram os capi das redes sefarditas (judeus ibéricos e seus descendentes) que arrematavam os lotes no Recife e revendiam com juros para os senhores locais.
} 
de 1660, após várias gestões diplomáticas. Entrementes, como se pode presumir, os bens dos vencidos ficaram à deriva, a partir de 1654, e coube a Francisco Barreto de Menezes, como governador, administrar este imbróglio. Não só este, mas outro mais grave, como foi a reivindicação dos exilados na Bahia, durante a guerra, que exigiram a restituição dos bens confiscados pelos holandeses e depois leiloados para os luso-brasileiros leais à Companhia das Índias Ocidentais.

Eis algumas questões cruciais na trajetória de Francisco Barreto como general e depois governador, de Pernambuco e do Estado do Brasil, para pensarmos o acúmulo de uma fortuna que levaria à instituição de um morgado.

\section{Excluído do panteão restaurador}

Pode causar espanto que Francisco Barreto de Menezes seja personagem tão acanhado na historiografia sobre as guerras holandesas no Nordeste açucareiro do século XVII. Não na historiografia pernambucana especializada, é claro, nicho de grandes historiadores brasileiros, mas da historiografia brasileira em geral. Nos livros didáticos de História e coleções sobre História Colonial, Francisco Barreto é figura ausente, ou quase, e não constava do panteão tradicional dos restauradores pernambucanos.

Poucos conhecem a Lei n. 12.701, assinada pela Presidenta Dilma Rousseff, em 6 de agosto de 2012, mandando incluir no "Livro dos Heróis da Pátria", depositado no Panteão da Pátria e da Liberdade Tancredo Neves, os nomes de Francisco Barreto de Menezes, João Fernandes Vieira, André Vidal de Negreiros, Henrique Dias, Antônio Filipe Camarão e Antônio Dias Cardoso. Este último ainda é menos conhecido, embora valoroso nas guerras flamengas, conhecido como "mestre das emboscadas" desde o Monte das Tabocas, em 1645.

Muito mais conhecido é Henrique Dias, comandante do Terço negro desde a resistência, nos anos 1630; nomeado, por Carta Régia, "governador dos negros", com a missão de "queimar canaviais e fustigar os holandeses". Perdeu uma das mãos em batalha, o que não o impediu de comandar seus homens, no "Arraial dos Pretos", até a vitória final. Recebeu, então, de d. João IV, a comenda dos Moinhos de Soure, da Ordem de Cristo, além da repartição de algumas fazendas e propriedades em Pernambuco e dois mil cruzados em dinheiro para repartir entre os soldados que comandara. Em março de 1656, viajou a Portugal para requerer satisfação por serviços prestados, visto que o prêmio era muito inferior ao recebido pelos demais restauradores. Pediu foros de fidalgo para si e seus genros, além da alforria para os soldados e oficiais escravos que haviam lutado sob o seu comando. A questão foi resolvida pelo Conselho Ultramarino que, alforriando os negros combatentes, indenizou, modestamente, os proprietários menores e obteve a manumissão dos senhores ricos. ${ }^{3}$ Henrique Dias não ficou fora do decreto de 2012, embora condenado pelas alas mais radicais do movimento negro no

\footnotetext{
${ }^{3}$ MELLO, José Antônio Gonsalves de. Henrique Dias. Recife: Massangana, 1956.
} 
país, visto como contraponto a Zumbi dos Palmares. De fato, ele comandou expedições contra os quilombolas nessa época. ${ }^{4}$ Ao longo da guerra contra os holandeses, capturou, para si e seus genros, diversos escravos confiscados pelo exército restaurador. Henrique Dias era escravista e, talvez por isso, Francisco Adolpho de Varnhagen o tenha incluído no panteão dos restauradores, em sua História Geral do Brasil, afirmando que ele renunciara aos defeitos da sua raça para servir ao rei de Portugal.

O potiguar Filipe Camarão, por sua vez, é uma unanimidade entre os historiadores como herói da restauração pernambucana desde os cronistas coloniais. Também lutou contra os holandeses em 1630 e recebeu do rei o hábito de Cavaleiro da Ordem de Cristo, o direito de usar o título de Dom e brasão de armas, com soldo de capitão-mor dos índios, e tença de 40 mil réis, além de terras em Portugal - das quais jamais tomou posse. Faleceu e 1648, antes da segunda batalha dos Guararapes, travada no ano seguinte.

Já Francisco Barreto de Menezes permaneceu no ostracismo até o decreto de Dilma Rousseff. Na tradição historiográfica brasileira, como se sabe, construiu-se a lenda de que a Insurreição Pernambucana exprimiu a união das "três raças" formadoras contra o invasor estrangeiro" $^{5}$ - a negra, a indígena e a portuguesa - representadas, respectivamente, por Henrique Dias, Filipe Camarão e André Vidal de Negreiros, natural da Paraíba, expoente da açucarocracia pernambucana. João Fernandes Vieira, autêntico líder da insurreição, foi por vezes ofuscado por André Vidal, em especial por Varnhagen, que considerava André Vidal moralmente mais digno. João Fernandes, além de mulato, natural da Madeira, enriquecera durante o governo de Nassau.

No imaginário político pernambucano, João Fernandes é sempre citado em primeiro lugar. Evaldo Cabral de Mello nos explica, em Rubro Veio, as origens do panteão oficial dos restauradores emergente no início do século XVIII e consagrado entre 1817 e 1824, ao tempo que Pernambuco articulou seu projeto emancipatório, republicano e lusófobo. ${ }^{6} \mathrm{Um}$ imaginário que, de início, era nativista e autonomista, muito antes de ser separatista, e incluiu, entre outros elementos, a canonização de uma tetrarquia de restauradores: João Fernandes Vieira, endeusado desde os cronistas do século XVII, símbolo dos reinóis que restauraram Pernambuco para a Coroa; André Vidal de Negreiros, filho de senhor de engenho, homem branco, representando a adesão da elite mazomba" à "guerra da liberdade divina"; Henrique Dias, comandante do Terço negro; Filipe Camarão, líder dos potiguares leais à Coroa.

\footnotetext{
4 MATTOS, Hebe. Da guerra preta às hierarquias de cor no Atlântico português. Atas do [...]. XXIV Simpósio Nacional da ANPUH. São Leopoldo, 2007. Disponível em: http://snh2007.anpuh.org/resources/content/anais/Hebe\%20Mattos.pdf. Acesso em: set. 2029.

5 VARNHAGEN, Francisco A. História das lutas contra os holandeses no Brasil. Rio de Janeiro: Biblioteca do Exército, 2002 [1871]; ABREU, Capistrano de. Capítulos de História Colonial. 6a ed. Rio de Janeiro: Civilização Brasileira, 1976 [1907], p. 96.

6 MELLO, Evaldo Cabral de. Rubro Veio: imaginário da restauração pernambucana. Rio de Janeiro: Nova Fronteira, 1986, p. 195-197.

7 Expressão depreciativa usada, no Pernambuco colonial, para designar os membros da elite senhorial, filhos de portugueses, naturais do Brasil.
} 
Nosso historiador realça que a tal "invocação tetrárquica" implicou uma dupla eliminação. De um lado, excluiu os líderes da resistência, sobretudo Matias de Albuquerque, conde de Alegrete, comandante das guerras de emboscada contra os flamengos entre 1630 e 1635; de outro lado, excluiu "quem fosse estranho a Pernambuco", e neste caso foi uma "exclusão discriminatória contra Francisco Barreto de Menezes", 8 comandante do exército restaurador entre 1648 e 1654. O desempenho militar e político do general, a partir de 1647, não deixa dúvida quanto à sua importância na guerra de restauração. Mas a tetrarquia oficial permaneceu inabalável no imaginário pernambucano. A "nobreza da terra", autoproclamada em Pernambuco, jamais admitiu que um forâneo ocupasse o lugar de João Fernandes Vieira, muito menos de André Vidal, como comandante e herói da restauração.

Mas quem foi, afinal, nosso personagem? Antes de tudo, era estrangeiro, por ter nascido no Peru, embora ele mesmo se dissesse natural de Madri. Até 1640 , se natural de Castela ou de colônias castelhanas não constituía desdouro para qualquer nobre português e parte da nobreza portuguesa mudou-se para Madri jamais regressando a Portugal. ${ }^{9}$ Mas isto mudou depois de 1640, durante a guerra de Portugal contra a Espanha, tempo em que a antiga proximidade com a dinastia filipina poderia causar embaraços ao indivíduo, conforme as circunstâncias. A origem castelhana de Francisco Barreto decerto pesou neta exclusão.

Francisco Barreto de Menezes nasceu provavelmente em 1619 - e não em 1616, como alguns afirmaram - filho de Francisco Barreto, comandante da fortaleza de Callao, nas cercanias de Lima, e Dona Isabel de Borja, embora esta filiação também seja polêmica, como veremos mais tarde. O pai de nosso personagem ilustra situação comum no tempo da União Ibérica: o fato de funcionários de origem portuguesa, nobres ou não, atuarem em domínios da Coroa castelhana e vice-versa.

Em 1637 recebeu, com cerca de 18 anos, o hábito de Cavaleiro de Santiago da Espada - uma das três Ordens militares de Portugal - o que já implicava alguma nobilitação, embora de segunda categoria. Recebeu tal mercê por serviços prestados pelo pai homônimo, inserido nas redes clientelísticas da Monarquia hispânica? Eis hipótese verossímil, mas nosso personagem foi, na verdade, criado na casa de Francisco de Borja y Aragón, nobre de linhagem, Príncipe de Esquilache, Vice-Rei do Peru entre 1614 e 1621 . Terminado o mandato, o príncipe regressou a Madri, levando consigo Francisco, então um menino de dois anos, que ali viveu até 1629. Neste ano, Francisco foi mandado a Portugal, onde passou viver, não se sabe na casa de quem. Provavelmente teve formação militar e jurídica, considerando a sua atuação posterior. Mas há um lapso documental na vida de Francisco desde os 10 até os 18 anos e idade. O próprio Francisco costumava, e propósito, embaralhar ou omitir informações sobre a sua ascendência.

Em 1638, no ocaso da União Ibérica, se ofereceu para "lutar no Brasil" contra os holandeses. Serviu ao rei de Espanha integrando, como capitão, a frota comandada pelo Conde

\footnotetext{
8 MELLO, Evaldo Cabral de. Rubro veio... Op. cit., p. 198.

${ }^{9}$ BOUZA ALVAREZ, Fernando. Portugal no tempo dos Filipes. Lisboa: Cosmos, 2000.
} 
da Torre, em 1639, incumbida de retomar Pernambuco. Uma represália à malograda tentativa holandesa de tomar a Bahia, em 1638. Mas a estreia do jovem Francisco no serviço do rei castelhano foi lastimável, pois a operação foi rechaçada pela marinha de Nassau. Francisco também lutou na Bahia, em 1640, outra vez contra os holandeses, quando Nassau retaliou a ação do Conde da Torre, canhoneando Salvador e incendiando alguns engenhos.

Regressando a Portugal, Francisco logo aderiu à Restauração portuguesa e lutou com destaque na guerra contra a Espanha, assumindo comando militar no Alentejo, foco das batalhas luso-castelhanas. Recebeu mercês por sua competência em combate. Foi homem típico na nobreza de serviço, ${ }^{10}$ que trocou a fidelidade à dinastia filipina pela causa restauradora liderada pela Casa de Bragança. Não é de admirar que o tenha feito, dentre os inúmeros portugueses que mudaram de lado, em 1640, considerando que o próprio duque de Bragança, antes comandante de Filipe IV em terra lusitana, aceitou ser aclamado rei de Portugal em 1640. Foi o desempenho militar de Francisco Barreto na guerra de Restauração que palmilhou sua ascensão ao estrelato. Pedro Calmon, em breve resumo da atuação militar de Barreto, escreveu ter sido ele "um dos maiores sodados de Portugal no século XVII. Ele só valia um exército...". ${ }^{11}$ Um exagero de Calmon, historiador clássico, em sua ode a Francisco Barreto.

Seja como for, d. João IV nomeou Francisco Barreto de Menezes, em 1646, para o comando do exército restaurador nas guerras pernambucanas. Isto equivaleu à substituição de João Fernandes Vieira, líder da rebelião irrompida em 1645, por um jovem oficial sem experiência em comandos gerais. Francisco mal chegava aos 30 anos quando foi designado para a posição. Esta decisão do rei constitui um mistério, assim dito e reafirmado por diversos estudiosos das guerras flamengas.

Além do mais, o dilema da "guerra brasílica", na corte portuguesa, era inseparável de uma questão de ordem diplomática, conhecida como "as pazes com a Holanda". Para resumir, desde 1641 Portugal negociava com os Estados Gerais neerlandeses a possibilidade de reaver as capitanias açucareiras no Brasil. A embaixada enviada a Haia foi desastrosa, de início, exigindo a devolução daquelas capitanias sob a alegação de que o Portugal restaurado era tão inimigo da Espanha como eram os holandeses. Argumento pífio e ingênuo: os diplomatas dos Estados Gerais agiam no interesse da WIC, exclusivamente preocupada com seus investimentos no Atlântico. Nos anos seguintes, os diplomatas portugueses baixaram o tom, propuseram comprar o nordeste açucareiro, aumentando o preço a cada reunião. A negociação estava neste ritmo, entre as crescentes exigências holandesas e o recuo português, quando irrompeu a revolta pernambucana.

Entre 1645 e 1646, os embaixadores portugueses em Haia não sabiam o que fazer, liderados por Francisco de Souza Coutinho com a assessoria do célebre Antônio Vieira. A corte

\footnotetext{
${ }^{10}$ RAMINELLI, Ronald. Nobrezas do Novo Mundo: Brasil e ultramar hispânico, séculos XVII e XVIII. Rio de Janeiro: Ed. FGV, 2015, p. 23-48.

${ }^{11}$ CALMON, Pedro. Francisco Barreto, restaurador de Pernambuco. Lisboa: Agência Geral das Colônias, 1940, p. 7.
} 
portuguesa, por sua vez, se dividiu entre "valentões" e "entreguistas", os primeiros favoráveis à guerra brasílica, os segundos ao prosseguimento das concessões diplomáticas. Evaldo Cabral de Mello tratou do assunto em livro clássico. ${ }^{12}$ A dinastia de Bragança adotou postura ambivalente e dissimulada. Assegurava que a rebelião pernambucana fora iniciativa dos colonos, oferecendo-se para reprimi-la a partir da Bahia. Secretamente, mandava instruções ao governador Antônio Teles da Silva para ajudar os insurretos.

A nomeação de Barreto tem a ver com a chegada a Lisboa, em 1646, do procurador da Câmara de Olinda, solicitando apoio da monarquia restaurada à guerra contra os holandeses, além de queixar-se de João Fernandes Vieira. Havia cerca de um ano que a rebelião tinha irrompido em Pernambuco e já se percebia, entre os graúdos da capitania, a rapinagem infrene de algumas lideranças, a começar por João Fernandes. Há farta evidência documental dos saques perpetrados em benefício de uns poucos.

Acatando parecer do Conselho Ultramarino, d. João IV decidiu nomear um chefe militar para a campanha, mas alertou que a ajuda material da Coroa deveria dissimular-se para evitar represálias flamengas. No final de 1646, nomeou Francisco Barreto a despeito das reservas do Conselho de Estado, que vetou seu nome por não ter ele "a idade, autoridade e a experiência necessárias" para o posto, acrescentando que, provavelmente, "não seria bem recebido no Brasil". Entre os opositores da nomeação de Francisco Barreto havia gente poderosíssima, como o veterano Matias de Albuquerque e o marquês de Nizza, que assumiria a embaixada portuguesa em Paris. O rei, porém, manteve a indicação.

Quem protegia o jovem Francisco de Barreto na Lisboa restaurada? Valentões interessados em apoiar a rebelião, transferindo o comando para um oficial lealíssimo a d. João IV? Hipótese frágil, à falta de fontes comprobatórias e considerando que havia militares mais experientes, a começar por Matias de Albuquerque. Era membro do Conselho de Estado que conhecia Pernambuco e o estilo da guerra brasílica desde os tempos da resistência. Mas se foi algum "valentão" que protegia nosso personagem, este pode ter sido João Rodrigues de Sá e Menezes, terceiro conde de Penaguião, camareiro-mor de d. João IV, esntusiástico da revolta pernambucana contra os graúdos do Conselho de Estado. Mas porque aventamos a hipótese de ter sido o conde de Penaguião, entre os valentões, o padrinho do jovem Francisco Barreto? Afinal, a ligação mais documentada entre Francisco Barreto e o conde de Penaguião só ocorreria muito mais tarde quando, de volta ao reino, o general contraiu matrimônio com uma filha do conde, em 1665. Evaldo Cabral de Mello sugere, porém, que a relação entre Francisco e a família Penaguião vinha de longe e ela "explicaria sua surpreendente designação" como mestre-de-campo do exército pernambucano. Voltaremos à questão oportunamente.

Uma segunda hipótese, mais difícil de provar, relacionaria a nomeação de Francisco Barreto aos conselheiros interessados em criar cizânia na cúpula dos rebeldes, contrariando João Fernandes e André Vidal, com o objetivo de enfraquecer a insurreição em favor da negociação com os holandeses. Trata-se de hipótese maquiavélica que, se demonstrável, teria

12 MELLO, Evaldo Cabral de. O negócio do Brasil. Portugal, os Países Baixos e o Nordeste, 1641-1669. Rio de Janeiro: Topbooks, 1998. 
o dedo de Antônio Vieira, o "embaixador oculto", ${ }^{13}$ o principal conselheiro do rei, o ideólogo da Restauração que afirmava, aos quatro ventos, que d. João IV se tornara rei por vontade de Deus. Vieira era contrário à guerra pernambucana, basta ler o seu "Papel Forte" de $1648 .{ }^{14}$

Francisco Barreto recebeu a patente em fevereiro de 1647 e partiu logo em março, primeiramente para a Bahia, incumbido de ali organizar o exército insurreto. Uma estratégia curiosa, pois implicava o apoio do Governador Geral, Antônio Teles da Silva, na Bahia, antes de submeter os líderes pernambucanos ao seu comando. Estaria, na verdade, incumbido de apoiar os rebeldes ou de reprimir a rebelião, conforme os diplomatas portugueses asseguravam aos holandeses em Haia? Infelizmente, afirma Gonsalves de Mello, não são conhecidas as "instruções secretas que certamente lhe foram entregues" ${ }^{15}$

O início da operação foi um fracasso. Chegando à Bahia, a frota portuguesa viu-se atacada por navios zelandeses fortemente armados. Para azar de Francisco Barreto, ele e seu adjunto já estavam nos patachos* para desembarcar em Salvador quando foram capturados. Francisco Barreto, ferido de raspão na cabeça por tiro de mosquete, foi levado preso ao Recife. Alegou que sua missão no Brasil era reprimir a rebelião, mas disso não convenceu as autoridades holandesas. Ficou preso até fins de janeiro de 1648, quando fugiu graças à ajuda de um soldado holandês, provavelmente subornado ou com promessa de sê-lo. Francisco Barreto buscou o front dos insurretos, na várzea do Capibaribe, e logo mandou notícia ao governador da Bahia. Este, por sua vez, oficiou a João Fernandes que dali em diante o comando geral seria de Francisco Barreto.

O novo comandante foi aceito pelos líderes da rebelião? Há controvérsias que não cabe aqui detalhar. Alguns cronistas afirmam que Francisco foi recebido "com obediência e bom ânimo", enquanto outros sugerem que João Fernandes e André Vidal mal disfarçaram sua contrariedade. Um cronista asseverou que Francisco Barreto, agindo com prudência, entregou o comando efetivo das operações a Vieira e a Vidal, reconhecendo a sua própria inexperiência nas lides da guerra brasílica. Mas houve, também, quem o considerasse, pelo contrário, o estrategista da vitória luso-brasileira, sobretudo nas duas batalhas dos Guararapes - decisivas da guerra - em 1648 e 1649.

\section{Administrando a "querela dos engenhos"}

\footnotetext{
${ }^{13} \mathrm{GROH}$, Thiago. O embaixador oculto: Antônio Vieira e as negociações entre Portugal e a República dos Países Baixos. Curitiba: Prismas, 2015.

${ }^{14}$ VAINFAS, Ronaldo. Guerra declarada e paz fingida na Restauração Portuguesa. Revista Tempo, Niterói (RJ), v. 14, n. 27, p. 82-100, 2009. Disponível em: http://www.scielo.br/scielo.php?pid=S141377042009000200007\&script=sci_abstract\&tlng=pt. Acesso em: set. 2019.

15 MELLO, José Antônio Gonsalves de (ed.). Testamento do General Francisco Barreto de Menezes. Recife: IPHAN, 1976, p. 11.
}

\footnotetext{
* Patachos são pequenos barcos à vela com dois mastros, na proa vela latina, na popa vela redonda, utilizado para transporte de cargas e reconhecimento litorâneo.
} 
Terminada a guerra, Francisco exerceu o governo de Pernambuco, transformada em capitania régia, até 1656 . Em agosto deste ano, foi nomeado governador geral do Brasil, ainda no reinado de d. João IV, passando o governo pernambucano para André Vidal. Assumiu o Governo Geral em junho de 1657, permanecendo dois triênios no cargo, que deixou em 1663.

De volta ao reino português, exerceu diversos postos de importância: membro do Conselho de Guerra, governador de Setúbal, Presidente da Junta de Comércio. Atravessou, incólume, diversas crises políticas, mantendo a confiança da monarquia - independentemente das facções que rivalizavam no poder, seja durante o reinado de Afonso VI, na regência do infante d. Pedro ou no próprio reinado deste último, como d. Pedro II. Faleceu no auge de seu prestígio, em 1688, aos 69 anos.

Se nos anos finais da guerra, Francisco Barreto conseguiu conviver e até se articular com João Fernandes e André Vidal, durante o seu governo em Pernambuco tais relações azedaram. O ressentimento daqueles com a manutenção do poder nas mãos de Francisco Barreto se tornou evidente. Durante todo o período, Francisco Barreto escreveu ao rei, que estava no fim da vida, dando conta dos focos latentes de crise presentes desde a guerra, documentação depositada no Arquivo Histórico Ultramarino.

Um dos maiores problemas de seu governo foi, sem dúvida, a "querela dos engenhos" examinada em Olinda restaurada. ${ }^{16}$ O problema remontava a dezembro de 1634 quando, conquistada a Paraíba, a resistência parecia não ter mais fôlego, nem recursos, para deter o avanço holandês. Aumentaram, então, as deserções nas fileiras de Matias de Albuquerque e do próprio governador da Paraíba, Antônio de Albuquerque. Bento do Rego Bezerra, por exemplo, grande senhor da capitania, bandeou-se para o lado flamengo em troca de manter seu patrimônio intacto. Duarte Gomes da Silveira, outro prócer regional, fez o mesmo, e logo confraternizaria com o conquistador. Até mesmo entre os jesuítas, que tinham atuado com bravura na luta, mobilizando aldeias indígenas e até pegando em armas, houve uma traição exemplar. Foi a do Padre Manoel de Moraes, que acabou recrutado como funcionário da WIC e passou a viver na Holanda como consultor da empresa neerlandesa. ${ }^{17}$

A erosão do campo resistente foi avassaladora. Não apenas pelas deserções e pelo colaboracionismo com os holandeses, mas também pela fuga de diversos senhores locais, uns temerosos do que Ihes fariam os holandeses, outros porque recusavam submeter-se ao inimigo herege. Estes fugiram para a Bahia levando a família, homens de confiança, agregados e escravos, embora muitos cativos tenham aproveitado o caos para fugir.

Vitoriosa na guerra, com a conquista do Arraial do Bom Jesus, em julho de 1635, a WIC tratou de acalmar os ânimos. Logo em janeiro de 1635, propôs uma negociação que ficaria conhecida como "Acordo da Paraíba", publicada por Varnhagen em livro clássico. Documento que, segundo o autor, foi pessimamente redigido, numa "linguagem tão estrangeirada que faz

\footnotetext{
16 MELLO, Evaldo Cabral de. Olinda Restaurada. Op. cit.

17 VAINFAS, Ronaldo. Traição: um jesuíta a serviço do Brasil holandês processando pela Inquisição. São Paulo: Companhia das Letras, 2008, p. 59-68.
} 
supor que haverá sido mal traduzido do holandês". ${ }^{18}$ Por meio dele, os holandeses garantiam paz e justiça contra quaisquer inimigos; asseguravam a propriedade e a proteção aos negócios, franqueando salvo-condutos para os que necessitassem viajar por mar ou terra; mantinham os impostos em vigor, sem aumentá-los; isentava os moradores e seus filhos da obrigação de servir em armas "contra forças vindas da metrópole"; garantia o direito de recorrerem a tribunais do lugar contra os próprios governantes e, ainda, de terem juiz segundo as leis e ordenações portuguesas; admitia o direito de usarem armas para a defesa contra salteadores e amotinados; reconhecia a liberdade de consciência e de culto com a devida proteção às imagens e aos sacerdotes papistas.

Tal acordo abriu caminho para a aliança entre a WIC e a fração da classe senhorial que apostou no sucesso da dominação holandesa. Os senhores que se recusaram a aceitar o domínio holandês deixaram terras e engenhos para trás, fugindo para a Bahia. Ficaram conhecidos como emigrados. Seus bens foram confiscados pela WIC e colocados em leilão, admitido o pagamento a prazo pelos arrematantes. Temos notícia de um desses leilões, realizado em 1637, quando 44 engenhos foram postos à venda. Foram 41 os compradores, sendo que 23 holandeses compraram 21 engenhos; 14 portugueses ou luso-brasileiros compraram 14 engenhos; 4 judeus compraram 6 engenhos, com destaque para o judeu Duarte Saraiva, um dos maiores negociantes estabelecidos em Pernambuco no pós-1630, que arrematou o Engenho Velho de Beberibe, o de Bom Jesus, no Cabo de Santo Agostinho, e o Engenho Novo, também no Cabo. ${ }^{19}$

Se a capitania de Pernambuco possuía cerca de 100 engenhos por volta de $1630,{ }^{20}$ somente no leilão de 1637 quase 45\% deles mudaram de mãos no início do governo de Nassau. Seria este o percentual dos emigrados que abandonaram seus bens na fuga para a Bahia? É difícil precisar, porque alguns tinham mais de um engenho e outros eram lavradores de cana, ora sesmeiros, ora arrendatários. E quando falamos em engenhos, não nos referimos apenas à agromanufatura do açúcar descrita em Grandeza e Opulência do Brasil por suas drogas e minas, do jesuíta Antonil (1711), mas também às roças, aos estábulos, aos barcos e, decerto, às casas-grandes. Não foi pequena, assim, a riqueza que os emigrados abandonaram na rota de fuga, seja na quantidade, seja na qualidade.

Antes mesmo da reconquista do Recife, os emigrados estavam ansiosos pela recuperação dos bens que os holandeses haviam confiscado e revendido com base no seu direito comercial moderno, atropelando o direito português, que assegurava a propriedade das terras outrora concedidas em sesmarias, desde que produtivas. Expulsos os holandeses, a "querela dos engenhos" veio à tona, em especial porque muitos líderes da rebelião se haviam apoderado dos engenhos confiscados. João Fernandes Vieira figurava entre eles. Passou de

\footnotetext{
${ }^{18}$ VARNAGEN, Francisco Adolpho de. História das Lutas..., Op. cit., p. 113.

${ }^{19}$ MELLO, José Antônio Gonsalves de. Gente da Nação. Recife: Massangana, 1996, p. 225-226.

20 Memória oferecida ao Conselho Político do Recife por Adriaen Verdonck em 1630. In: MELLO, José Antônio Gonsalves de. Fontes para a história do Brasil holandês: a economia açucareira. 2a ed. Recife: Companhia Editora de Pernambuco, 2004, p. 33-50.
} 
administrador do engenho de um holandês a sócio do empreendimento e, passados alguns anos, tornou-se proprietário de cinco engenhos, imensa escravaria, bois, cavalos, canaviais e muitas joias vindas de Amsterdã, tudo com o apoio de Nassau e créditos da WIC. João Fernandes fez de tudo para sabotar o pleito dos emigrados. Gaspar Dias Ferreira, outro dos "validos do conde Nassau", tomou posse das terras do mosteiro de São Bento da Paraíba na mão grande, alegando que os frades the haviam transferido as propriedades. Fez o mesmo com as terras dos carmelitas e franciscanos. Jamais foi encontrado um só documento comprobatório de tais doações. Poderíamos multiplicar os exemplos de tal conduta.

Logo se instalou a disputa sobre quem era dono do quê, tudo agravado por disputas entre herdeiros de algum emigrado falecido ou entre os herdeiros dos nouveaux riches pernambucanos. Francisco Barreto escreveu ao rei, em 12 de março de 1654, informando, sem delongas, que "hão de crescer as diferenças sobre estes pleitos, de modo que receio que haja uma guerra civil entre estes moradores". O governador resumiu as razões de cada grupo: os emigrados consideravam tremenda injustiça a perda de seus bens por terem sido leais vassalos e obedientes a um preceito real, enquanto os novos donos alegavam terem financiado a restauração de Pernambuco, "com suas fintas e donativos", além do que - alguns aduziam tinham comprado as terras e engenhos aos holandeses. ${ }^{21}$

A "querela dos engenhos" pôs em jogo dois modelos de propriedade rivais em termos jurídicos. De um lado, o direito ibérico, ancorado numa concepção patrimonialista que valorizava, antes de tudo, a propriedade régia dos domínios da Coroa, reconhecendo, porém, a propriedade útil que, embora evoque a propriedade senhorial, privativa da nobreza de linhagem, era terra concedida pelo rei para produzir e colonizar, como no caso das sesmarias. De outro lado, a noção da propriedade privada adotada pelos neerlandeses que, sem prejuízo da propriedade das antigas linhagens batavas, valorizava a mercantilização dos bens, a compra e a venda consensuais como critério de legitimação. ${ }^{22}$ Os emigrados defendiam o direito tradicional, ao passo que seus adversários sustentavam a lógica mercantil da propriedade. As duas facções realçavam, porém, a lealdade ao rei, embora a lealdade dos primeiros fora ao rei de Castela, quando fugiram para a Bahia, enquanto a dos segundos, agora fiéis à dinastia de Bragança, fora à WIC, no tempo dos flamengos.

Evaldo Cabral de Mello considera que a posição de Francisco Barreto foi hábil, em face do imbróglio, evitando tomar o partido de qualquer dos grupos. ${ }^{23}$ Estimulou o exame dos pleitos caso a caso, encorajando acordos, tudo conforme a importância e a qualidade dos pleiteantes. Homens como João Fernandes ou André Vidal ficaram com tudo que haviam obtido no tempo dos holandeses, além de agraciados com honrarias e cargos. Alguns emigrados

\footnotetext{
${ }^{21}$ MELLO, Evaldo Cabral de. Olinda Restaurada..., Op. cit., p. 283.

22 Ciro Flamarion Cardoso afirmou, em texto clássico, que havia duas grandes modalidades de propriedade da terra nas colônias escravistas da América: nas colônias francesas, espanholas e no Brasil português, a propriedade da terra tinha um caráter patrimonial ou mesmo 'dominial'; nas colônias inglesas e holandesas, "pelo contrário, um caráter nitidamente capitalista". Cf. CARDOSO, Ciro F. Agricultura, escravidão e capitalismo. Petrópolis, RJ: Vozes, 1979, p. 112.
}

${ }^{23}$ MELLO, Evaldo Cabral de. Olinda restaurada..., Op. cit., p. 424. 
recuperaram seu patrimônio ou parte dele, mediante indenização aos "novos donos". Os que tiveram mais sorte nesta disputa foram aqueles cujos bens tinham passado, por compra, à propriedade de holandeses e judeus portugueses vindos de Amsterdã. Retomaram suas terras, na ausência dos que as haviam comprado aos flamengos, deixando que as indenizações fossem assumidas pela Coroa em negociações diplomáticas. ${ }^{24}$

Francisco Barreto de Menezes assumiu o Governo Geral na Bahia em 1656, e continuou às turras com os líderes da ressurreição, ora por razões jurisdicionais, ora pelas disputas de propriedades, sem contar os ressentimentos pessoais. Dois meses depois de deixar o Governo geral, resolveu lavrar o seu famoso testamento, instituindo o seu patrimônio como morgado; estabeleceu a linha sucessória do morgadio; indicou credores e devedores; apresentou lista de seus bens e negócios. Um tesouro documental, que deixa questões em aberto, sobretudo porque o patrimônio do governador era relativamente modesto quando foi nomeado comandante em chefe da guerra pernambucana. Porque decidiu lavrar o seu testamento ainda no Brasil, se estava para regressar a Lisboa com boa expectativa de novos cargos, além de ter acertado casar-se com uma filha do conde de Penaguião? Qual a relação do patrimônio testado e a querela dos engenhos que ele administrou como governador?

\section{O testamento do general}

O testamento de Francisco Barreto permite alcançar aspectos pouco conhecidos dos morgadios no Brasil Colonial, em comparação com aqueles do reino no Antigo Regime português. É importante considerar que sua decisão por instituir um morgado não era mero capricho ou somente uma forma de consagrar sua trajetória nas guerras pernambucanas. Há uma relação intrínseca entre propriedade vinculada e operacionalização do passado como elemento legitimador do direito a bens, sobretudo terras, marcadas pela indivisibilidade patrimonial em favor do primogênito. ${ }^{25}$ Ademais, sua decisão em instituir um morgado construiria um ponto zero na qualificação de seu patrimônio, com base no direito tradicional lusitano, independentemente de querelas sobre o direito de propriedade emergentes no post bellum pernambucano e, por razões subjetivas, beneficiando herdeiros de uniões concubinárias.

A redação do testamento foi confiada a Frei Francisco de Salles e coube ao tabelião Antônio Cardoso da Silva registrar o documento, atestando, como de praxe, que Francisco de Menezes estava "em perfeito juízo". Francisco registrou o desejo de ser enterrado no Convento

\footnotetext{
24 Pelo tratado de 1661, Portugal se comprometeu a indenizar as Províncias Unidas em quatro milhões de cruzados no prazo de 16 anos, bem como a pagar as dívidas dos credores holandeses e judeus. As dívidas relacionadas aos judeus perfaziam $68 \%$ do total devido. A liquidação das dívidas aos particulares só ocorreu em 1692. Os judeus foram os últimos a receber e nem todos foram devidamente ressarcidos. Cf.: VAINFAS, Ronaldo. Jerusalém Colonial. Rio de Janeiro: Civilização Brasileira, 2010, p. 354-355.

${ }^{25}$ MOTTA, Márcia. Minha casa, minha honra. Morgadios e conflito no Império Português. In: MONTEIRO, Rodrigo Bentes; et al. (eds.). Raízes do privilégio: mobilidade social no mundo ibérico do Antigo Regime. Rio de Janeiro: Civilização Brasileira, 2011, p. 639-666.
} 
de São Francisco dos Capuchos da vila de Loulé, no Algarve, porque ali estava a sepultura os pais. Mas quem eram os pais? Francisco não explicita os nomes no testamento. Se no início do artigo identificamos o comandante de Callao, Francisco Barreto, e Dona Isabel de Borja, foi com base no documento em que Francisco solicitou licença pra casar, em 1665, como de fato se casou, com Dona Maria Francisca de Sá, filha do conde de Penaguião.

Em todo caso, a omissão do nome dos pais no testamento foi acompanhada, ainda, de informações falsas, como a de que nascera e fora batizado em Madri, ao invés de Lima, no Peru. Neste e noutros pormenores se pode perceber a deliberada intenção do testador de enevoar as suas origens. No caso da origem familiar, Gonsalves de Mello acrescenta haver até dúvida sobre quem foi a mãe do general, havendo um códice na Biblioteca Nacional de Lisboa com registro de que seu pai "o houve natural em Dona Ana, natural de Salamanca, filha de um desembargador". ${ }^{26} \mathrm{O}$ historiador assegura, ainda, que outro documento registra que a mãe de Francisco Barreto de Menezes era "mulher nobre e casada", mas não com o pai de nosso personagem. Um romance secreto, portanto, fruto de adultério. De modo que, fosse D. Isabel ou D. Ana a mãe de Francisco, ele era, no primeiro caso, bastardo, e no segundo, ilegítimo.

Também cabe conjecturar sobre o Francisco Barreto pai, que somente aparece na documentação nas tratativas de 1665 para o casamento do general com a filha do conde Penaguião. Seria mesmo Francisco Barreto o pai de Francisco Barreto de Menezes? O fato é que, ainda menino de dois anos, ele foi levado para Madri pelo Príncipe de Esquilache, Don Francisco de Borja y Aragón, nobre que governara o Vice Reinado do Peru. Não escapou a Gonsalves de Mello que a mãe de Francisco tinha o mesmo sobrenome Borja do Príncipe de Esquilache. Seria Francisco de Borja y Aragón o verdadeiro pai de Francisco de Barreto de Menezes com uma moça "nobre e casada" de sua própria família? É possível, mas ainda assim ficamos sem saber o grau de parentesco entre Francisco de Borja y Aragón e Dona Isabel.

Quanto mais investigamos a ascendência do general, mais aumenta a incerteza. O fato é que o Francisco de Borja y Aragón despachou o menino para Portugal com dez anos de idade, em 1629, decerto encaminhando-o a algum nobre português, dentre os vários aliados da dinastia filipina. O próprio Francisco Barreto de Menezes serviria, como vimos, à dinastia filipina nas operações do Conde da Torre, entre 1638 e 1639, na Bahia e em Pernambuco. Em 1641, Francisco já aparece entre os jovens oficiais do Portugal restaurado.

Não é de admirar, portanto, que tenha se esforçado tanto em omitir dados de sua origem familiar, ou mesmo falseá-los, seja no testamento, seja nos papéis matrimoniais. À diferença de muitos filhos ilegítimos ou bastardos da nobreza ibérica, inclusive na família real, nosso general não foi reconhecido pelo pai, fosse quem fosse. Sua origem era uma nódoa que precisava ser ocultada. Acrescentemos, enfim, um indício iconográfico, convidando o leitor a dar uma vista d'olhos no Retrato de Francisco Barreto, de autoria anônima, mas datado do XVII, considerado o mais autêntico retrato do general. A imagem sugere que Francisco Barreto era mulato, o que não chega ser um argumento decisivo, pois existem muitos retratos de

\footnotetext{
${ }^{26}$ MELLO, José Antônio Gonsalves de. Testamento..., Op. cit., p. 9.
} 
homens célebres de cor parda, na história brasileira, que aparecem "embranquecidos" inclusive do mesmo Francisco Barreto, para não falar de João Fernandes Vieira. Mas se Francisco Barreto tinha "sintomas de mulatice", para usar a linguagem racista da época, eis outro complicador decisivo para as suas pretensões nobilitantes.

Figura I - Retrato de Francisco Barreto de Menezes.

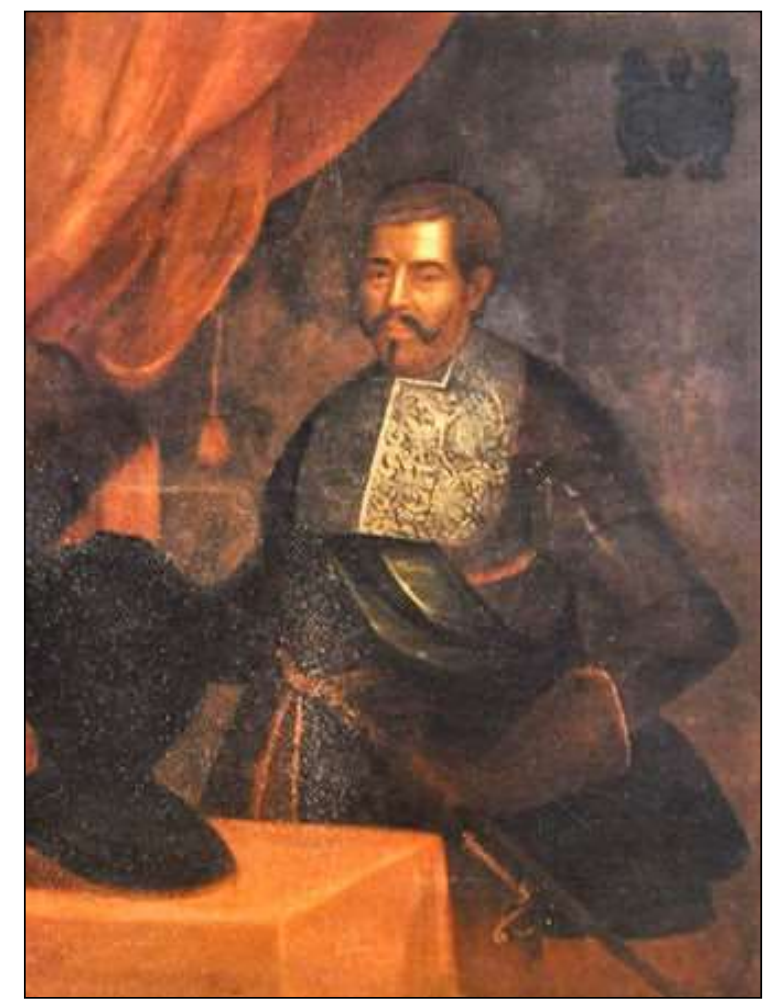

Fonte: Museu do Estado de Pernambuco. [S.n.t.]

Não menos interessante é o cuidado que teve nosso general em nomear, pela ordem, os testamenteiros. Indicou Rui de Figueiredo; Dom Francisco de Castello Branco; Martim Correa da Silva e, na falta dos três, Martin Gonçalves de Souto. Os três primeiros eram homens da Restauração e cavaleiros da Ordem de Cristo, sem prejuízo de terem servido aos castelhanos antes de 1640. Rui de Figueiredo era fidalgo da Casa Real, ex-comandante de Trás-os-Montes quando Francisco servia no Alentejo contra os castelhanos; de Francisco de Castelo Branco, parece ter sido homem da nobreza, mas há tantos homônimos que mestre Gonsalves de Mello foi econômico nas informações; Martim Correia da Silva era "moço fidalgo" e foi governador do Algarve; Martim Gonçalves do Souto, o último na linha dos testamenteiros, era "homem de negócio", morador na Bahia, entre 1649 e 1651.

Voltaremos a alguns desses nomes no artigo. Por ora, vale indagar a quem o general legou seu patrimônio, visto ser solteiro quando fez o testamento. Legou a seus filhos naturais - exatamente como ele - frutos de relações "ilícitas", a primeira com "mulher honesta e honrada", a quem não nomeou, a segunda com Serafina de Jesus, "igualmente honesta e honrada". Eram eles Manuel Barreto - o primogênito - e Gonçalo Nunes Barreto, Antônio Moniz 
Barreto e Dona Francisca de Aragão. Serafina estava grávida, na altura em que Francisco fez o testamento, no qual determinou sua reclusão em convento, comprometendo-se a pagar a tença anual como dote e permitindo que Serafina ao menos escolhesse a casa de reclusão. Pouco se sabe sobre os filhos de nosso personagem, tampouco de suas mães, além do que dissemos acima. Do primogênito, cujo nome da mãe Francisco omitiu, Gonsalves e Mello afirma não saber se era baiana ou pernambucana, mas não é impossível que fosse natural do reino. Os filhos de Serafina devem ter nascido no Brasil, considerando que se tratava de relação recente, pois a mulher estava grávida dele.

Vale insistir no ponto em que Francisco fixou em testamento, sem nenhum constrangimento, o destino de sua companheira, mãe de três filhos, sem contar o que estava por vir: um convento. Não poderia ser o de Santa Clara do Desterro, na Bahia, o primeiro do Brasil, que só seria fundado no Brasil em 1677. Francisco Barreto não tinha a menor intenção de desposá-la, explicitando que devia se tornar freira - como se a mulher fosse parte de seu patrimônio - para contar com o devido sustento. É provável que já tivesse acertado o matrimônio com a filha do conde de Penaguião, seu protetor na corte brigantina nos anos 1640.

Mas não deixa de causar certo espanto o açodamento do general em vincular todo o patrimônio que havia acumulado - pouco no reino, a maior parte no Brasil - ao primogênito de sua primeira concubina e, na falta dele, aos filhos que tivera com Serafina, também concubinária, já que estava a ponto de contrair núpcias com a filha do Penaguião. Testamento em 1663, em benefício de filhos naturais; matrimônio em 1665, com filha de nobre português: conduta intrigante de nosso general.

O mais importante, porém, reside na instituição do morgadio. Os demais filhos só seriam herdeiros do patrimônio na falta do primogênito, por morte, na ordem de seus nascimentos, com explícita preferência pelos varões, de modo que a filha só herdaria o morgadio se os irmãos mais velhos não tivessem filhos varões, ou se a criança que Serafina carregava no ventre fosse menina.

O morgadio integrava, portanto, antes de tudo, a legislação concernente à sucessão e à herança dos bens de um chefe de família ou domicílio (inclusive se esposa) a seus descendentes. É fato bem conhecido dos estudiosos que os direitos de herança e sucessão na legislação lusitana derivaram, em linhas gerais, do Direito Romano e do Direito Islâmico, mas se inspiraram, mais diretamente, nos códigos de Castela, conforme indica a vasta literatura jurídica sobre a matéria. ${ }^{27}$

O assunto encontra-se no Livro IV das Ordenações Filipinas, que combinam tradições jurídicas (seculares e canônicas) com direitos costumeiros, retomando, em inúmeros tópicos, o que já estava disposto, quer nas Ordenações Afonsinas (1446), quer nas Manuelinas (1513). Para o assunto que nos interessa, as Ordenações Filipinas, de modo geral, reconheciam que os bens de um casal legítimo pertenciam aos cônjuges por igual (meação), salvo se o contrato

27 MERÊA, Manuel Paulo. Novos Estudos de História do Direito. Barcelos: Editora do Minho, 1937. 
nupcial estabelecesse alguma divisão diferente do patrimônio conjugal. Quanto à sucessão dos bens, a herança legítima passava ao cônjuge sobrevivente que, no entanto, só poderia dispor da terça parte dela, só fazendo jus à totalidade se não houvesse ascendentes ou descendentes, o que era raríssimo. Quanto ao restante da herança, deveriam os 2/3 beneficiar, de preferência de forma igualitária, os filhos e filhas legítimos ou, na falta deles, os netos e netas, mesmo no caso dos filhos naturais, desde que reconhecidos pelo pai. No entanto, no caso de haver testamento registrado em cartório, o testador poderia dispor livremente do seu legado material, sendo incomum que os bens fossem legados de maneira desigual, com privilégio da varonia e por vezes da primogenitura. Na falta de testamento registrado, as regras de divisão prevaleciam na elaboração do inventário post mortem do patrimônio. O patrimônio familiar dividido por vários herdeiros, respeitando a legítima e o terço, podia se fracionar. No caso da propriedade fundiária, as terras legadas tornavam-se alodiais, isto é, livres e passíveis de alienação. ${ }^{28}$

As sutilezas jurídicas acima justificam a preocupação de Nuno Gonçalo Monteiro em distinguir herança e sucessão, pois a primeira podia ser partilhada entre os descendentes, ao passo que a segunda provinha do "direito vincular", privilegiando apenas um sucessor - o "imediato sucessor" - observada a primogenitura e a varonia nas sucessões subsequentes. ${ }^{29}$

Outra distinção fundamental é a que se deve observar entre casa e linhagem. O autor esclarece que linhagem é a família, ou melhor, o nome de família considerado socialmente nobre, aristocrático, seja por antiguidade, seja por grandes feitos, em geral militares, de seus ancestrais, invariavelmente varões. A família, como se sabe, nada tem a ver com a noção de família nuclear que se construiu no Ocidente ao longo da Época Moderna, mas a uma parentela alargada, no espaço, e remota, no tempo.

A casa, por sua vez, deve ser entendida como "um conjunto coerente de bens simbólicos e materiais a cuja reprodução alargada estavam obrigados todos os que nela nasciam ou dela dependiam". A casa possuía, quase sempre, um referente territorial, fosse senhorio ou morgadio, mas seu reconhecimento assentava, necessariamente, em títulos nobiliárquicos, quando menos comendas ou ofícios palatinos. Nuno Monteiro acrescenta que, após a Restauração de 1640, a linhagem perdeu a importância de outrora em face do conceito de casa, sem desaparecer, porém, como marca da aristocracia portuguesa. ${ }^{30} \mathrm{~A}$ casa, claro está, nada tem a ver com domicílio ou morada, senão com o status nobiliárquico da família.

Mas Francisco Barreto se tornou homem rico que, ao instituir o seu morgadio, seguiu o espírito do direito português quanto à desigualdade entre os sucessores e a exclusão das mulheres, salvo na ausência total de descendentes varões. O que destoa, no caso de

\footnotetext{
${ }^{28}$ FERNANDES, José Miguel. Entre o público e o privado, entre a metrópole e o Império. Testamentos nas misericórdias portuguesas. Revista Portuguesa de História, Coimbra, t. XLVII, 2016, p. 215-235.

29 MONTEIRO, Nuno G. Trajetórias sociais e formas familiares: o modelo de sucessão vincular. In: CHACÓN, F.; FRANCO, Juan H. (eds.). Família, poderosos y oligarquias. Murcia: Universidad de Murcia, 2001, p. 15.

${ }^{30}$ MONTEIRO, Nuno G. Trajetórias sociais e... Op. cit., p. 30-31.
} 
Francisco, além de sua biografia em nada aristocrática, é o teor dos bens incluídos no morgado.

O testamento estabelecia que, depois de pagas as dívidas reconhecidas pelo testador, todo o resto devia ser anexado ao morgadio, o que incluía terras, rendas, foros, joias de ouro ou prata e até dinheiro "de contado"- como se chamava à época, o dinheiro em espécie, amoedado.

O patrimônio do general incluía bens ou rendas no reino: $20 \%$ de rendas auferidas dos "bairros de Dona Constança, na vila de Santarém"; juros da Coroa consignados no Almoxarifado do Algarve; rendas de duas terras de que era proprietário no mesmo Algarve; foros que tinha em Paderna, na mesma região, como os da Quinta de Quarteira, nos arredores de Albufeira. Esta última renda estava em pendência judicial: Francisco Barreto alegava que as rendas da quinta eram de "de seus pais e avós", sem nomeá-los, como sempre, enquanto seus adversários no pleito sustentavam que pertenciam a um morgado. E quais eram os querelantes de Francisco Barreto nessa pendência? O Príncipe de Esquilache e certo Antônio de Mendonça. Eis um fato desconcertante: o príncipe de Esquilache, talvez o verdadeiro pai de Francisco Barreto de Menezes, querelava Francisco sobre a Quinta da Quarteira. A diferença para o desfecho do pleito residiu em que o príncipe de Esquilache era homem leal aos Habsburgos, enquanto Francisco Barreto era homem da Restauração portuguesa no reino e no ultramar. A quinta foi integrada ao morgado do general.

Quanto aos bens que Francisco possuía no Brasil, eles eram relativamente modestos: um trapiche e quatorze casas que tinha no Recife, arrendadas por dez anos a Diogo de Santiago; um patacho, que reconhece ter naufragado nos Açores; $25 \%$ de uma fragata, 50\% de outra; um baú com moedas de prata espanholas e "dobrões singelos"- valiam 20 mil réis cada uma; cordão de ouro da ordem de Cristo; vários objetos de prata: salvas tinteiros, talheres, jarros, cálices, bacias etc.

Francisco Barreto também arrolou quantias que a Coroa portuguesa Ihe devia, algumas elevadas, estimadas em milhares de cruzados: vários empréstimos; prêmios pela atuação militar no Brasil "antes da aclamação" (isto é, no período filipino) e pelo comando na restauração do Recife; quatro mil cruzados em sentença judicial contra o Príncipe de Esquilache, cujos bens, em Portugal, haviam sido confiscados pelo rei d. João IV. O total dessas dívidas incluídas pelo general em seu morgadio alcançavam 16 mil cruzados, o que equivalia, na época, a cerca de 130 escravos de Angola. ${ }^{31}$ Uma fortuna, embora, neste caso, Francisco Barreto estava na expectativa de recebê-la, não a tinha em seu poder.

É verdade que o testamento previa que, pagas as dívidas, "todos os bens restantes deviam empregados em bens de raiz, livres e capazes de se anexarem em morgadio". Mas noutra passagem do testamento, ao referir-se ao trapiche, ao patacho, à metade de uma fragata e ao dinheiro que "tinha em seu baú", Barreto determinou que fossem incorporados ao

31 PUNTONI, Pedro. A mísera sorte: a escravidão africana no Brasil holandês e as guerras no Atlântico Sul. São Paulo: Hucitec, 1999, p. 176. 
seu morgado. ${ }^{32}$ Qual era a intenção de Francisco Barreto? Que os bens móveis fossem vendidos pelo primogênito e investidos em terras? Mas se os bens de um morgado eram inalienáveis, como efetuar tais operações de acordo com o princípio do direito vincular português? É presumível que os bens móveis inclusos em um morgadio, apesar de inalienáveis, eram passíveis de entrar no mercado. Dificilmente a Coroa poderia controlar o comércio de baixelas ou talheres de prata, muito menos a circulação de dinheiro em espécie. Em termos estritamente patrimoniais, somente os bens de raiz ficavam vinculados ao primogênito com tais restrições inamovíveis, sem que houvesse anuência da Coroa. As terras de um morgadio não podiam servir como garantia de empréstimos ou hipotecados.

Seja como for, o certo é que o morgadio instituído pelo general englobava a propriedade de terras, rendas fundiárias, dinheiro, joias e créditos. Parte acumulada em Portugal, outra parte no Brasil, tudo incluído no morgado. O mesmo se pode constatar em outros testamentos que instituíram morgados no mundo colonial. Morgados incertos, não raro destoantes, em vários aspectos, dos morgadios portugueses tradicionais, fosse pela qualidade dos envolvidos, fosse pela composição dos bens legados.

\section{De "militar pobre a homem de grande fortuna"}

O título acima é como José Antônio Gonsalves de Mello resumiu a trajetória de Francisco Barreto de Menezes desde que assumiu o comando da guerra contra os holandeses, em 1647, até deixar o governo do Estado do Brasil, em 1663, ano em que redigiu o seu testamento. ${ }^{33}$ Foi também mestre Gonsalves de Mello quem publicou este valioso documento, com excelente introdução e notas complementares em 1976, várias vezes citadas neste artigo.

Francisco Barreto se tornou "homem de grande fortuna" em meio à "querela dos engenhos" post bellum? Aproveitou-se do cargo para acumular patrimônio fundiário? Não há evidência clara de peculato na documentação sobre a sua gestão da "querela dos engenhos". Francisco Barreto - repitamo-lo - foi "homem de serviço": vale o citado juízo que dele fez Evaldo Cabral como "hábil" na administração deste problema do post bellum pernambucano.

A única situação polêmica, neste particular, ocorreu a propósito do engenho do Moreno, na freguesia do Jaboatão, pertencente à condessa de Penaguião, sogra de nosso personagem, que o vendeu em 1689 a certo João de Barros Rego - Francisco Barreto já era falecido. Houve que acusasse o governador de ter facilitado a aquisição desse engenho pela futura sogra, quando governou Pernambuco, ou mesmo que tenha dele se apropriado nos anos 1650, para depois vendê-lo à condessa. A proximidade do governador com a casa de Penaguião, consolidada em 1655 pelo matrimônio com uma filha do conde, estaria na base deste suposto favorecimento à condessa. Contudo, examinando diversos manuscritos relativos à propriedade,

\footnotetext{
32 MELLO, José Antônio Gonsalves de. Testamento... Op. cit., p. 20.

${ }^{33}$ Ibidem, p. 14.
} 
Evaldo Cabral nega qualquer parcialidade do governador no caso. O engenho já era de propriedade dos Penaguião antes da restauração pernambucana, não constando da lista de terras devolutas em 1655, muito menos no rol de bens do governador em seu testamento. ${ }^{34}$

Além disso, para afunilar o argumento, lembremos o contraste entre o patrimônio "brasileiro" arrolado por Francisco Barreto no seu testamento com os bens listados no testamento de João Fernandes Vieira, seu antecessor no comando da guerra pernambucana. O testamento de Vieira não sobreviveu na íntegra, mas, nas peças disponíveis, constam nada menos do que dezesseis engenhos de sua propriedade; dez léguas de terras incultas no sertão de Santo Antão, em Pernambuco; outras tantas léguas no litoral do Rio grande e mais algumas, de extensão não identificada, na ribeira do Açu, na mesma capitania; várias fazendas em Pernambuco, nomeadamente em Maranguape, Maria Farinha, Jaguaribe e outros sítios, todos em Pernambuco; várias casas no Recife, em Olinda e na Paraíba. João Fernandes chegou a possuir fortuna de mais e um milhão e meio de cruzados, não sabemos se incluindo os bens imóveis ou apenas os recursos auferidos no comércio. Também era dono de um patacho e uma fragata, além de "enorme escravaria". ${ }^{35}$

André Vidal de Negreiros, o segundo no panteão dos restauradores, fez constar em seu testamento cinco engenhos, um deles em Pernambuco, dois em Itamaracá e um na Paraíba, de onde era natural, incluindo a escravaria; 22 currais de currais de gado vacum "com os escravos necessários"; terras no Caricé, na ribeira do Maranguape e na ilha Tiriri, com escravos e bois; três mil braças de terras junto aos currais; dez léguas no Rio da Paraíba; dois chãos e um sobrado no Recife; uma sumaca* e certa quantidade de prata não especificada.

A única semelhança entre o testamento de Francisco Barreto e os dos citados heróis resume-se a que os três, quando legaram seus bens, não tinham filhos legítimos, somente filhos naturais. Francisco Barreto reconheceu os seus filhos e os incluiu no testamento. João Fernandes casou-se em 1643 com Maria César, filha do João Berenguer de Andrada, escravista na Madeira, e de Joana de Albuquerque, descendente de Jerônimo de Albuquerque. O matrimônio consagrou a sua inserção na "nobreza da terra", embora fosse mulato. André Vidal jamais se casou e, embora tivesse filhos naturais, não os reconheceu, instituindo uma Capela em devoção a Nossa Senhora do Desterro como beneficiária de seu patrimônio.

O patrimônio de Francisco Barreto de Menezes era modesto, se comparado ao de João Fernandes e ao de André Vidal. João Fernandes, como já vimos, enriqueceu exatamente no período de dominação holandesa. Em 1645, deu enorme calote na WIC, de quem era o segundo maior devedor no Brasil, e ainda aumentou seu patrimônio, primeiramente com saques das propriedades de judeus e holandeses e, depois, na "querela dos engenhos". Também adensou seu patrimônio como governador da Paraíba, entre 1655 e 1657, e como

\footnotetext{
34 MELLO, Evaldo Cabra de. Olinda restaurada... Op. cit., p. 397-399.

35 MELLO, José Antônio Gonsalves de. Testamento... Op. cit., p. 24.
}

* Sumaca é um barco pequeno de dois mastros utilizado em comércio interno no litoral do Brasil colonial. 
capitão-general de Angola, entre 1658 e $1661 . .^{36}$ Já a riqueza de André Vidal resultou, sobretudo, dos confiscos perpetrados na guerra de restauração.

A "grande fortuna" que Gonsalves de Mello atribui a Francisco Barreto só se justifica em comparação os bens que possuía antes de ser nomeado comandante geral da revolta pernambucana. Francisco Barreto de fato enriqueceu ao longo dos 15 anos em que esteve no Brasil, primeiro no supremo comando militar, depois como governador de Pernambuco, enfim como Governador Geral. Enriqueceu como comerciante, conforme detalha Gonsalves de Mello examinando o seu testamento com pente fino. Enriqueceu com: 1) mercadorias vendidas principalmente em Lisboa, mas também no próprio Pernambuco e Angola, incluindo açúcar, âmbar, madeiras nobres, a exemplo do jacarandá; 2) movimentação de dinheiro no mundo português por meio de letras de câmbio, com percentual de juros, cobrindo dívidas de outrem ou mesmo empréstimos, como o que fez a Francisco Fernandes Furna, com garantia hipotecária de engenhos na Paraíba; 3) fretamento de suas embarcações para transporte de mercadorias de outros negociantes.

Eis o principal caminho para a formação das fortunas acumuladas pelos administradores coloniais - é o que nos demonstra a grande historiadora Virgínia Rau em "Fortunas Ultramarinas e a nobreza portuguesa no século XVII". ${ }^{37}$ Rau verticaliza a sua análise através dos testamentos de Antônio Teles da Silva, lavrados em 1645 e 1650, ele que substituiu o marquês de Montalvão no governo da Bahia, em 1642. Manteve relações estreitas com Francisco Barreto de Menezes e o apoiou, politicamente, em detrimento de João Fernandes, em 1647.

Filho caçula de família grada, Antônio Teles nada tinha de seu, como herança, exceto algum mobiliário, e seguiu carreira militar. Sua fortuna se fez muito depois, como de praxe, por meio do comércio e das finanças, na governança do Brasil. Quase nada de bens de raiz, salvo foros modestos de terras na metrópole, entre mercês recebidas no tempo da União Ibérica e nos primeiros tempos da Restauração. Seus bens provinham do comércio com açúcar branco e mascavado, fretamento de barcos, empréstimos. Fortuna similar à de Francisco de Barreto Menezes. Também não se casou, nem tinha filhos naturais. Legou parte do seu patrimônio a instituições religiosas e o restante ao irmão Fernão Teles de Menezes. Ele instituiu, também, um morgadio onde predominavam rendas financeiras, e não propriedades fundiárias. $^{38}$

Virgínia Rau comenta esta tendência, alegando que tais homens, ansiosos por alguma nobilitação, recorriam à testas-de-ferro como operadores dos negócios, para não manchar a reputação com o exercício de atividade considerada vil - o comércio e as finanças - no Antigo Regime europeu. No caso de Francisco Barreto, o primeiro testamenteiro, Rui de Figueiredo,

\footnotetext{
${ }^{36}$ MELLO, José Antônio Gonsalves de. Mestre de campo João Fernandes Vieira. Recife: Universidade do Recife, 1956, vol. II, p. 203-ss.

37 RAU, Virgínia. Fortunas ultramarinas e a nobreza portuguesa no século XVII. In: Estudos de história económica e social do Antigo Regime. Lisboa: Presença, 1984.

38 Testamento de Antônio Teles da Silva. In: RAU, Virgínia. Estudos de história... Op. cit., p. 36-41.
} 
além de amigo do testador, estava metido em atividades financeiras, e o último, Martim Gonçalves de Souto, era "homem de negócios" de origem cristã-nova. Alguns governadores do Brasil acionavam, como testas-de-ferro de seus negócios, cristãos-novos que viviam na Itália ou na Holanda, na França ou na Inglaterra - "terras de liberdade", como diziam os judeus portugueses em tais exílios, pois nelas eles podiam assumir o judaísmo sem constrangimento.

O grande paradoxo reside em que tais homens da Coroa, não obstante envolvidos no comércio e nas finanças até a raiz dos cabelos, aspiravam à nobilitação, fosse de que grau fosse. Assim, enriqueciam como negociantes, não raro associados à Gente da Nação, ${ }^{39}$ mas tão logo se sentiam seguros, buscavam se nobilitar, postulando mercês ou títulos ao rei e instituindo morgadios também integrados por riqueza móvel, sujeita às diatribes de um mercado mundial em gestação.

Seria exagero, porém, presumir que Francisco Barreto e seus contemporâneos da guerra restauradora no Brasil desejavam fundar casas e linhagens ancoradas em morgadios. João Fernandes Vieira, homem riquíssimo, não instituiu morgadio em seu testamento. Só possuía filhos ilegítimos e, até onde sabemos, distribuiu seus bens entre os herdeiros. ${ }^{40}$ Contentou-se $\mathrm{m}$ alcançar uma nobilitação de segunda categoria - duas comendas da Ordem de Cristo - e um cargo honorífico no Conselho de Guerra. No mais, continuou exercendo cargos de governo no ultramar e realizando negócios de grosso trato. André Vidal também não fundou morgadio, como vimos, e legou seus bens à instituição de uma capela. Sua maior recompensa foi a nomeação para a governança de Pernambuco, do Maranhão, da Paraíba e também de Angola, substituindo, em 1661, o companheiro de guerra João Fernandes. Antônio Teles da Silva, também enriquecido no comércio de grosso trato, acalentou maiores ambições, pois fundou morgadio em benefício do irmão, Fernão Teles da Silva, e recebeu promessa de título nobiliárquico, o de conde de Vila Maior. Morreu em 1650 sem ver a cor do título, mas seu irmão, Fernão Teles, foi titulado três anos depois por decisão de d. João IV. Antônio Teles da Silva foi, portanto, um daqueles que fundou casa e linhagem dentre os governadores coloniais, inclusive com morgadio gerado em negócios ultramarinos.

Francisco Barreto, a exemplo dos acima citados, foi nomeado para cargos importantes ao sair do Brasil. Mas sua nobilitação ocorreu por via tradicional, por assim dizer, primeiro ao casar-se com a filha do conde de Penaguião, segundo ao casar-se outra vez, sendo viúvo, com a filha do conde de São Miguel. Sua primeira filha legítima casou-se com nobre de linhagem, o que enfim Ihe rendeu um título nobiliárquico, o de conde do Rio Grande. Seria tal título alusivo ao atual Rio Grande do Norte? Possivelmente, mas não sabemos ao certo.

Seja como for, a nobilitação de alguns governadores coloniais nada teve a ver com a instituição de morgadios em testamento. Morgadios que não se sabe se foram devidamente

\footnotetext{
39 Gente da Nação designava os cristãos-novos, fossem católicos que viviam no mundo português ou judeus reconvertidos na diáspora. A expressão completa era "Gente da Nação hebreia".

40 João Fernandes foi acusado de irregularidades no governo de Angola, quase teve os bens sequestrados, mas conseguiu se livrar das acusações. Cf.: MELLO, José A. G. de. Mestre de campo... Op. cit., p. 353-354.
} 
autorizados pela Coroa, o que somente uma pesquisa verticalizada poderia esclarecer. O morgadio criado por Antônio Teles da Silva pode muito bem ter sido reconhecido pela Coroa, considerando que seu irmão - e sucessor no morgado - recebeu título nobiliárquico. Quanto ao de Francisco Barreto, prevalece a dúvida. Nosso general tinha alguma intenção nobilitante no testamento, ao estabelecer que o detentor do morgado "seguirá sempre o apelido de Barreto e usará das armas do mesmo apelido". Nesta cláusula, Francisco Barreto indicou a pretensão de fundar uma linhagem, um nome de família, apesar de o sucessor Manuel Barreto ser filho natural. E, apesar dele mesmo, Francisco Barreto, ser filho bastardo jamais reconhecido pelo pai, cujo nome é motivo e incerteza. Porém, o mais importante, para concluir, é que tais morgadios se formaram, em grande medida, a partir do comércio praticado à sombra e através de cargos no Brasil.

Virgínia Rau resume o sentido desta atitude dos governadores ultramarinos, como Antônio Teles ou Francisco Barreto:

\begin{abstract}
A nobreza, arredada nos negócios, por imperativos de classe, contornou tal impedimento social confiando a profissionais a gerência ativa de suas fortunas. Era a estes homens de negócio que incumbia vender e comprar mercadorias, aceitar e passar letras, e emprestar dinheiro a juros. Mãos limpas umas, e mãos sujas, outras, em face das atividades mercantis, quase sempre suspeitas, e de empréstimos, quase sempre condenáveis, pela jurisprudência e pelos conceitos sociais da época. ${ }^{41}$
\end{abstract}

Eis uma aparente contradição na formação das fortunas de administradores coloniais, ciosos de suas obrigações como representantes do rei. Não lesavam a Coroa, mas combinavam o público e o privado, o serviço à metrópole e a atuação mercantil - vocação portuguesa - não raro através dos principais financistas lusitanos: os cristãos-novos. Como aspirantes a alguma nobilitação, alguns instituíam morgadios, sonhando com títulos de nobreza ou com a fundação de linhagens. Voltemos à Virgínia Rau sobre tal percurso:

A capitalização nobre aplicou-se, entre nós, em rendas fixas e em morgados. Não obstante de início impulsionar correntes mercantis-financeiras, mal atingia certo volume, tornava-se estática, mercê da imobilização perpétua dos capitaisbase. E com cada fortuna vinculada se interrompia um circuito; o capital nobre fixado de vez não voltava a movimentar futuras transações comerciais. ${ }^{42}$

Francisco Barreto foi, como governador de serviço, leal à Coroa, fosse qual fosse a dinastia, filipina ou brigantina. Militar e administrador, nem por isso deixou de enriquecer no serviço dos reis. Mas não o fez em prejuízo da Coroa, senão como herdeiro de rendas fundiárias em Portugal e, sobretudo, como negociante no Brasil. A mistura do público com o privado era legítima na época. Era regra, desde que o Erário Régio não fosse lesado em demasia, conforme as circunstâncias e o arbítrio dos conselhos reais. Eis uma face importante do atraso ibérico na Época Moderna, bem como do arcaísmo brasileiro em suas raízes coloniais.

\footnotetext{
${ }^{41}$ RAU, Virgínia. Estudos de história... Op. cit., p. 35.

${ }^{42}$ Idem.
} 


\section{Referências}

ABREU, Capistrano de. Capítulos de História Colonial. 6a ed. Rio de Janeiro: Civilização Brasileira, 1976.

BOUZA ALVAREZ, Fernando. Portugal no tempo dos Filipes. Lisboa: Cosmos, 2000.

BOXER, Charles. Os Holandeses no Brasil. São Paulo: Cia. Ed. Nacional, 1961.

CALMON, P. Francisco Barreto, restaurador de Pernambuco. Lisboa: Agência Geral das Colônias, 1940.

CARDOSO, Ciro. Agricultura, escravidão e capitalismo. Petrópolis, RJ: Vozes, 1979.

FERNANDES, José M. Entre o público e o privado, entre a metrópole e o Império. Testamentos nas misericórdias portuguesas. Revista Portuguesa de História, Coimbra, t. XLVII, 2016.

GROH, Thiago. O embaixador oculto: Antônio Vieira e as negociações entre Portugal e a República dos Países Baixos. Curitiba: Prismas, 2015.

MATTOS, Hebe. Da guerra preta às hierarquias de cor no Atlântico português. Atas do [...]. XXIV Simpósio Nacional da ANPUH. São Leopoldo (RS), 2007. Disponível em http://snh2007.anpuh.org/resources/content/anais/Hebe\%20Mattos.pdf. Acesso em: set. 2019.

MELLO, Evaldo Cabral de. O negócio do Brasil. Portugal, os Países Baixos e o Nordeste. Rio de Janeiro: Topbooks, 1998.

MELLO, Evaldo Cabral de. Olinda Restaurada. 2a ed. Rio de Janeiro: Topbooks, 1998.

MELLO, Evaldo Cabral de. Rubro Veio: imaginário da restauração pernambucana. Rio de Janeiro: Nova Fronteira, 1986.

MELLO, José Antônio Gonsalves de. Fontes para a história do Brasil holandês: a economia açucareira. 2a ed. Recife: Companhia Editora de Pernambuco, 2004.

MELLO, José Antônio Gonsalves de. Gente da Nação. Recife: Massangana, 1996.

MELLO, José Antônio Gonsalves de. Henrique Dias. Recife: Massangana, 1956.

MELLO, José Antônio Gonsalves de. Mestre de campo João Fernandes Vieira. Recife: Universidade do Recife, 1956.

MELLO, José Antônio Gonsalves de. Tempo dos Flamengos. 3a ed. (aumentada). Recife: Massangana, 1987.

MELLO, José Antônio Gonsalves de. Testamento do General Francisco Barreto de Menezes. Recife: IPHAN, 1976.

MERÊA, Manuel Paulo. Novos Estudos de História do Direito. Barcelos: Editora do Minho, 1937. MONTEIRO, Nuno. G. Trajetórias sociais e formas familiares: modelo de sucessão vincular. In: CHACÓN, F.; FRANCO, Juan H. (eds.). Família, poderosos y oligarquias. Murcia: Universidad de Murcia, 2001.

MOTTA, Márcia. Minha casa, minha honra. Morgadios e conflito no Império Português. In: MONTEIRO, Rodrigo Bentes; et al. (orgs.). Raízes do privilégio: mobilidade social no mundo ibérico do Antigo Regime. Rio de Janeiro: Civilização Brasileira, 2011.

PUNTONI, Pedro. A mísera sorte: a escravidão africana no Brasil holandês e as guerras no Atlântico Sul. São Paulo: Hucitec, 1999. 
RAMINELLI, Ronald. Nobrezas do Novo Mundo: Brasil e ultramar hispânico, séculos XVII e XVIII. Rio de Janeiro: Ed. FGV, 2015.

RAU, Virgínia. Fortunas ultramarinas e a nobreza portuguesa no século XVII. In: Estudos de história económica e social do Antigo Regime. Lisboa: Presença, 1984.

VAINFAS, Ronaldo. Guerra declarada e paz fingida na Restauração Portuguesa. Revista Tempo, Niterói (RJ), v. 14, n. 27, p. 82-100, 2009. Disponível em: http://www.scielo.br/scielo.php?pid=S1413-

77042009000200007\&script=sci_abstract\&tlng=pt. Acesso em: set. 2019.

VAINFAS, Ronaldo. Jerusalém Colonial. Rio de Janeiro: Civilização Brasileira, 2010.

VAINFAS, Ronaldo. Traição: um jesuíta a serviço do Brasil holandês. São Paulo: Companhia das Letras, 2008.

VARNHAGEN, F. A. História das lutas contra os holandeses no Brasil. Rio de Janeiro: BIBLIEX, 2002. 